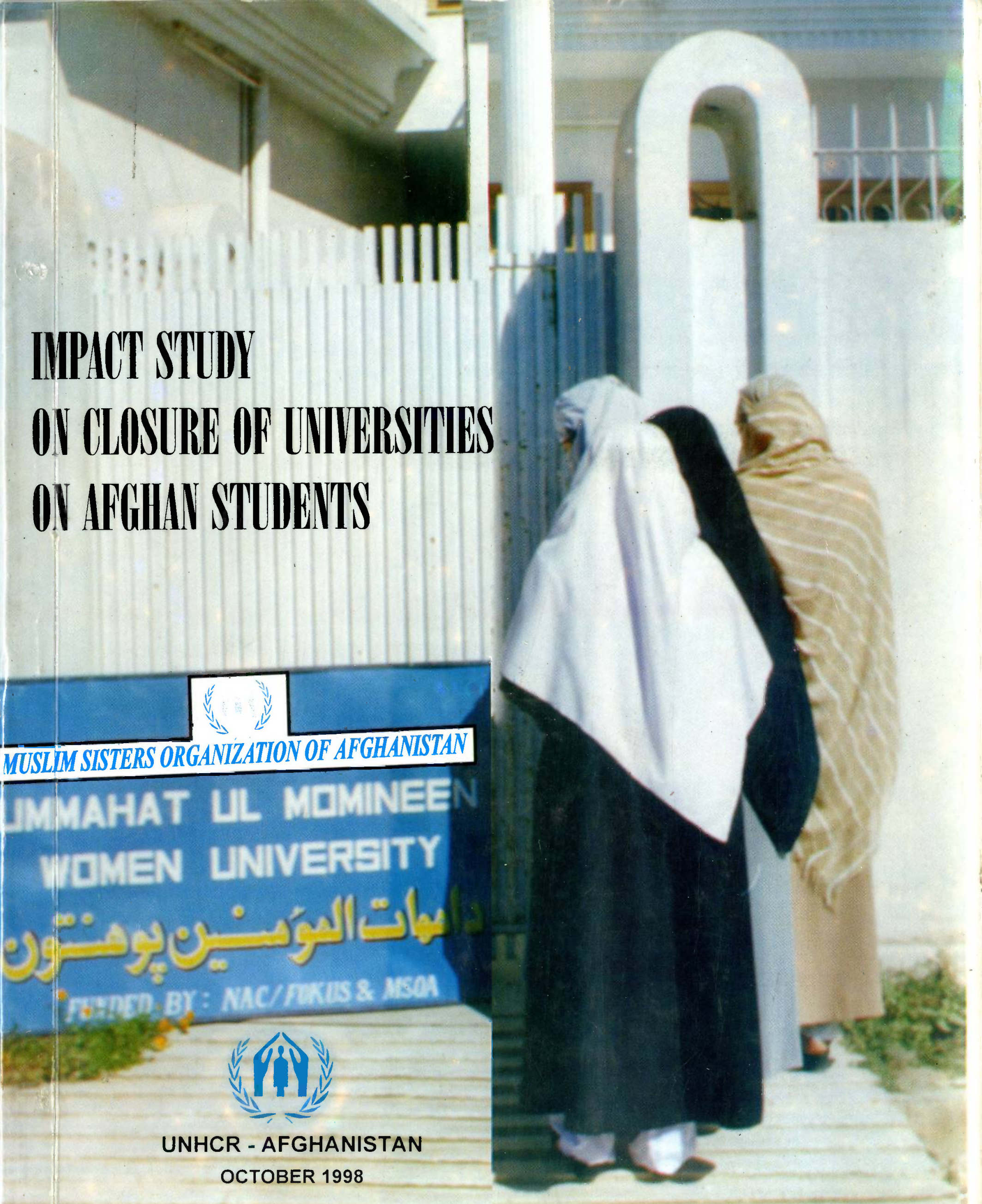




\title{
IMPACT STUDY
}

\author{
$O N$ \\ CLOSURE OF UNIVERSITIES \\ ON
}

AFGHAN STUDENTS
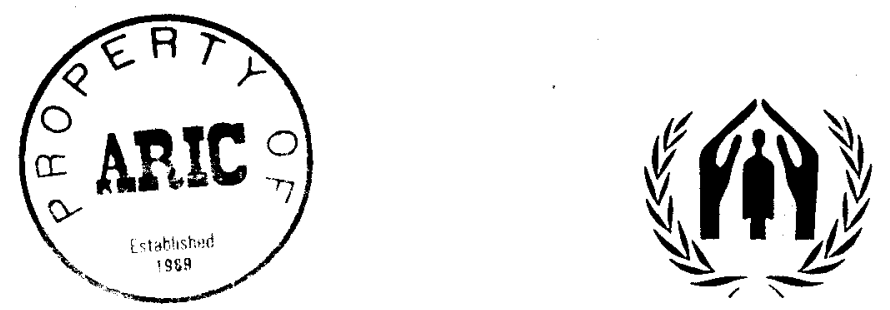

UNHCR - AFGHANISTAN

OCTOBER 1998 


\section{Gonfents}

\section{INTRODUCTON}

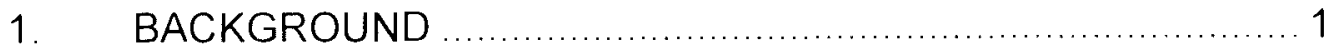

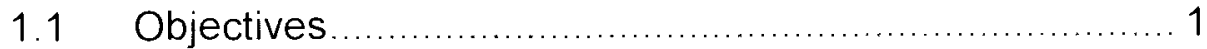

1.2 Methodology ......................................................... 1

1.3 Limitations of the study ........................................ 1

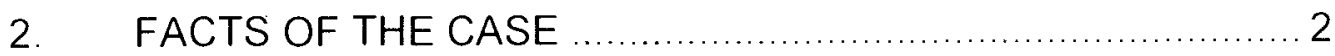

3. ISSUES

3.1 Registration of Universities ..................................... 3

3.2 Sub-standard quality of the universities...................... 4

3.3 Management .................................................... 6

3.4 Finance .............................................................. 6

3.5 Admissions of Pakistani students ................................ 7

3.6 Reactions from Taliban leadership ........................... 8

4. PROBLEMS ENCOUNTERED BY THE STUDENTS .............. 9

5. IMPACT OF CLOSURE ON THE STUDENT ...................... 10

5.1 Hospitality fatigue ................................................ 11

5.2 Commercial competitions ..................................... 11

5.3 Setting up education institutes and employment ........... 11

5.4 Delaying the desire to go home............................... 11

6. FINDINGS AND RECOMEMNDATIONS ….................. 12-13

\section{ANNEXURES}

1. Fact Sheet of Universities .............................................. 14

II. Court Decision .............................................................. 18

III. University Personnel ..................................................... 19

IV. Persons Interviewed .................................................... 24

\section{TABLES}

1. Basic Data of Universities .............................................. 2

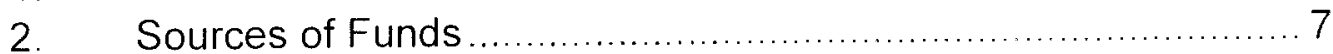




\section{INTRODUCTION}

The study on the closure of the universities in Peshawar was undertaken by the UNHCR, Kabul office notably to understand the underlying issues, their impact on Afghan education and to propose some remedial action. It should be emphasised that over the two decades, children of Afghan refugees, using the hospitality and facilities provided in Pakistan have moved from the primary to the university level. The current scenario amongst the Afghan student is thus a natural progression which has to be understood, underscored and fostered by those responsible. To avoid providing viable avenues for higher education. both inside Afghanistan and Pakistan, will mean the education of a significant portion of the educated Afghans will be compromised with all its attendant implications for the future

The study, with its limitations, indicates the apparent causes and the possible underlying reasons for the closure. It also reflects the fact that the universities were demand oriented. The commitment of the Afghan elder educationists and the keen interest of the females to continue their studies are two other factors that emerge from this study. The findings call for a more in depth study. More specifically the responsibilities of the international community in providing education at the higher level for the refugees and a similar quality facilities for education for returnees is highlighted.

In carrying out this study I am very grateful to Ms Marie-France Sevestre. Head, and Mr. Niaz Ahamad, Associate Programme Officer, UNHCR Sub Office, Peshawar for their guidance and logistic support provided to the two research officers from UNHCR. Kabul Office, Islamabad. A special word of thanks to Dr. S.B. Ekanayake and Dr. (Ms) Painda Saima who conducted the study and provided a report within a short time. I also appreciate the support that the Heads of NGO,s and Universities have given to the two UNHCR colleagues in carrying out the study

Ahmed Farah Chief of Mission

Afghanistan Islamabad 


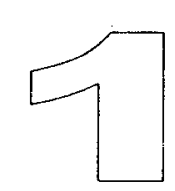

\section{BACKGROUND}

Ever since the influx of refugees from Afghanistan to Pakistan commenced two decades ago, the pressure to meet the needs of refugees has been growing. Most of these needs were met by UNHCR and the government of Pakistan. Of these education has been the prime need of almost everyone. Opening of schools, specially in the NWFP and a host of private institutions in the Peshawar, Islamabad, Quetta and elsewhere for the Afghan children, was a common feature over the years. Although not all children of the refugees were in a position to attend schools, a vast number benefited by these facilities. As a result and in due course of time the brighter children moved up the school cycles and qualified for higher education, facilities for which were provided on an ad hoc basis initially with the Universities in Peshawar and elsewhere. But later the Afghans, using their own resources, opened higher education institutions to accommodate their children. There were no objections to setting up these institutions by the local authorities and over the years these functioned to provide degrees in various disciplines. The successful Afghans found employment in Pakistan and as well as outside the country of refuge. All these meant development of human resources that could be made use of to assist the needs in Afghanistan when peace would prevail at some future date. This was a laudable goal. However, since of late these higher educational institutes were closed suddenly in July 1998 by the local government in the North Western Frontier Province of Pakistan. Naturally this step has caused a lot of undue stress on the Afghan students. The purpose of this study is to find out the causes for the closure of the Afghan universities and its implications on the higher education of the refugee children.

\section{$1.1 \quad$ Objectives}

1 to identify the reasons for the sudden closure of the universities

2 to asses the impact of the closure of the universities on the education of Afghans

3. to asses the impact of the closure on repatriation

\section{$1.2 \quad$ Methodology}

1. Discussions with key personnel concerned with education including Pakistani officials and political leaders

2. Interviewing students and parents

3. Visits to the institutions (Afghan and Pakistani)

4. Use of literature and materials related to the subject

For all of the above different schedules were developed.

\subsection{Limitations of the study}

1. Short duration and inability to contact a greater number of persons

2. Inability to meet the local authorities/visits to Pakistani universities

3. Inability to meet Taliban authorities 


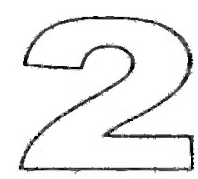

\section{FACTS OF THE CASE}

Currently four universities run by Afghans are in operation for Afghan students in Peshawar. This is in addition to another university run by a Pakistani national for Afghans. The former include Ummahat-ui-Momineen (1989). Hewad, Seyad Jamalud Din Afghan and Ahmad Shah (1993). Although there is no co-education all universities have female staff and students but follow ciasses separately. Of these Ummahat-ul-Momineen University is exclusively for women. The total number of students in ali universities amounts to 3020 out of which over 1200 are females $(40 \%)$, which is a very satisfactory participation of females. The total number on the academic staff of all the universities is 564 .

Table 1. Basic Data of Universities

\begin{tabular}{|c|c|c|c|c|c|c|c|}
\hline University & $\begin{array}{c}\text { Date } \\
\text { Estab. }\end{array}$ & \multicolumn{2}{|c|}{ No.of students } & $\begin{array}{c}\text { No.of } \\
\text { courses }\end{array}$ & $\begin{array}{l}\text { No. of } \\
\text { Staff }\end{array}$ & $\begin{array}{c}\text { Fee } \\
\text { Charged }\end{array}$ & $\begin{array}{c}\text { Assistance } \\
\text { received }\end{array}$ \\
\hline Momineen & 1990 & - & 731 & 03 & 120 & 100 & Rs. $8.6 \mathrm{~m}$ \\
\hline Hewad & 1997 & 448 & 102 & 04 & 40 & & ' \\
\hline $\begin{array}{c}\text { Seyad } \\
\text { Jamaluddin }\end{array}$ & $1995 \cdot$ & 450 & 200 & 04 & 48 & $300 / 400 /-$ & - \\
\hline $\begin{array}{c}\text { Ahamad } \\
\text { Shah Abdali }\end{array}$ & 1993 & 1153 & 212 & 05 & 88 & $300 / 400 \%$ & - \\
\hline TC & & 2051 & 1245 & & 296 & & - \\
\hline
\end{tabular}

Seemingly these universities have been established over five years and the number of students of al! the institutions have been increasing, indicating the growing need for tertiary education. The disciplines taught include Medicine. Engineering. Literature, Shariat and Agriculture. All lecturers are Afghans and are mostly former members of the faculties of universities inside Afghanistan. specially from the University of Kabul. Most of them state that they posses post-graduate degrees, both masters and Ph. D's from United States. UK. Germany. France, Holland, Russia, Poland. Australia. India.

Of these only Momineen University receives assistance from an NGO, namely Norwegian Afghanistan Committee, which is around Rs. 8.6 million. All others depend on the fees collected from the students which varies from Rs. 300 to 400 -a month. A lesser amount is collected from female students, and free transport is provided to all females as a measure of motivation and encouragement to study.

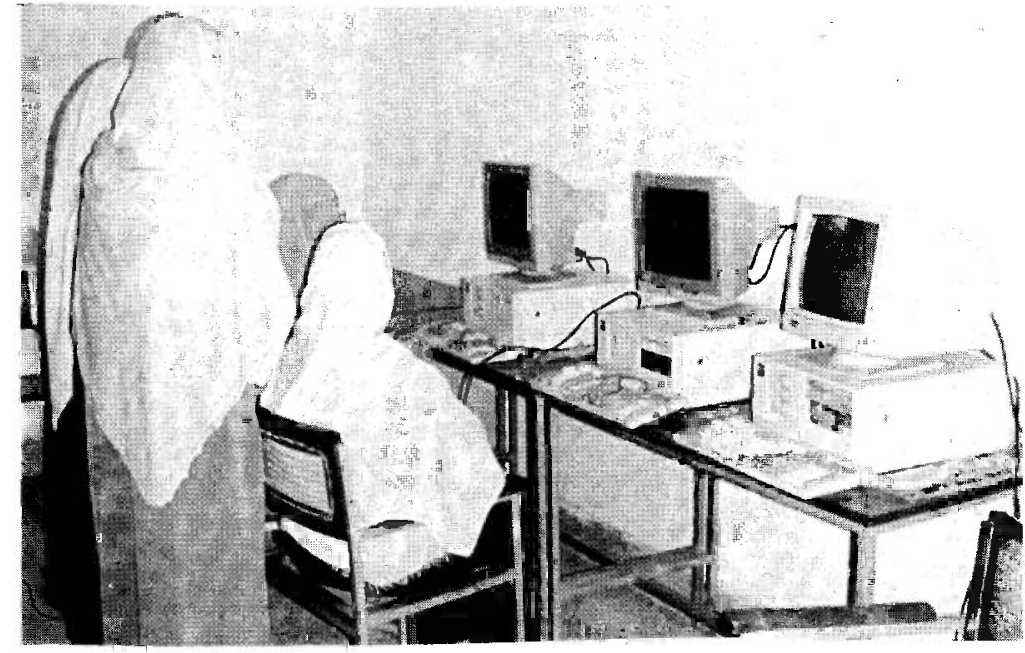

Students following computer courses 


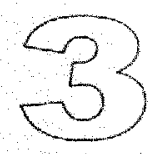

\section{ISSUES}

The issues that led to the closure of the Universities relate to the following

1. the universities been not registered with the Pakistani authorities

2 the relatively low standards of the products of the universities

3. enrollment of students from Pakistan in these universities

4 involvement of the unversity teachers during the communist regime in Afghanistan

The findings of this study will be discussed in the perspective of the above issues in order to provided better indepth understanding

\subsection{Registration of Universities}

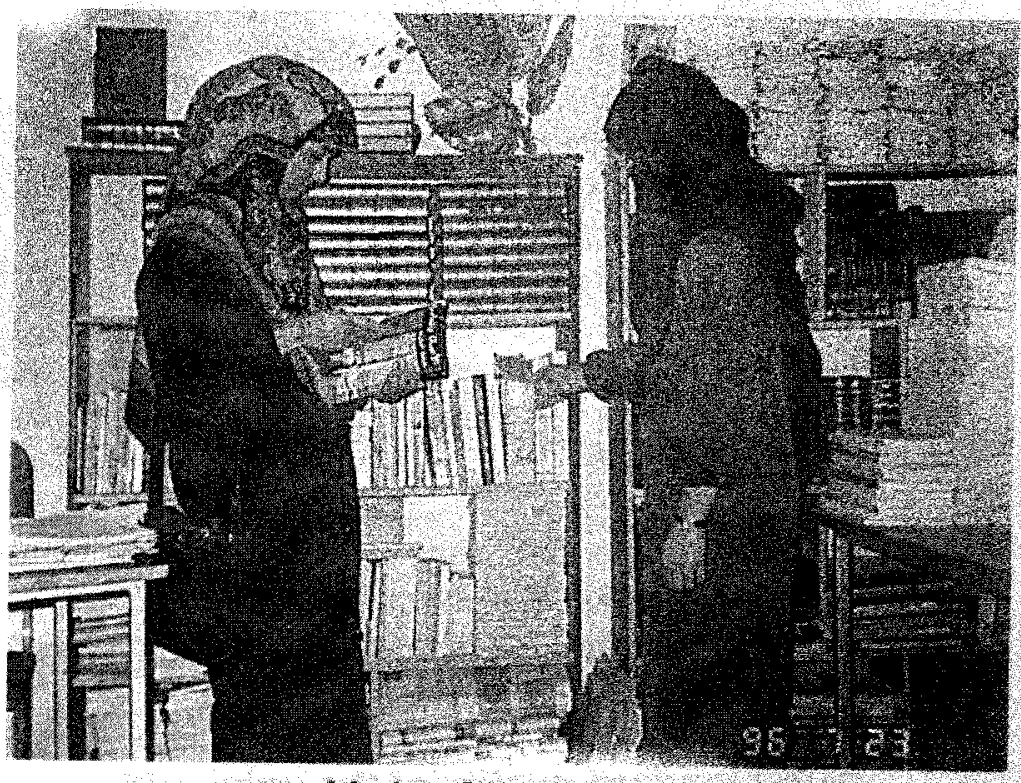

Mollest Library

The NWFP government closed the Afghan Universities in July, 1998. As a result of the closure two of the four universities, namely Ahamad Shah Abdali University and Seena University filed action against the local authorities at the Peshawar High Court. The argument regarding the closure included inter alia that these were business ventures and were illegally operating on Pakistan soil. These were further supported by a report of a committee appointed by the local administration, headed by a professional which had recommended the closure of these private universities

There is little information regarding this aspect of closure other than the above. Some unversities had receved no objection certificates (NOC) from the Commissionarate for Afghan Refugees but no formal approval had been given to any of the universities by the local authorities. According to the University authorities they had permission from the Commissionarate of Afghan Refugees, who has direct authority over the affairs of the refugees. Hence they claim that these institutions cannot be called illegal and as ones established in secreoy

Thus the contention of the university authorities regarding registration is that as these institutions have been functioning over a period of time without been questioned or reprimanded over non registration they are therefore in a quandary and question the bona fide of the decision. They even attempt to connect the sudden closure to political reasons rather than with academic issues. This is apparently due to the timng of the closure which was close in time to missile attack and subsequent agtation by Afghans in Peshawar. The unversites also feel rather disturbed about the modus operandi and the exact manner in which the closure took place. No prior information, correspondence or intimation had taken place about the closure over which the university authorities feel slighted. 
However, there had been a few occasions where non-academic personnel had suddenly visited the premises on several occasions, specially Momineen university (1994, 1996,1997,1998), followed lastly by an academic group on a fact finding mission. The personnel from the government of Pakistan inspected the laboratories, library. office and inquired about the needs. But the authorities at the university were never informed verbally or otherwise about the objectives or the findings of these visits. The Momineen university had provided a video on the activities of the university who were encouraged and sounded positive in their interactions with the officials of the university.

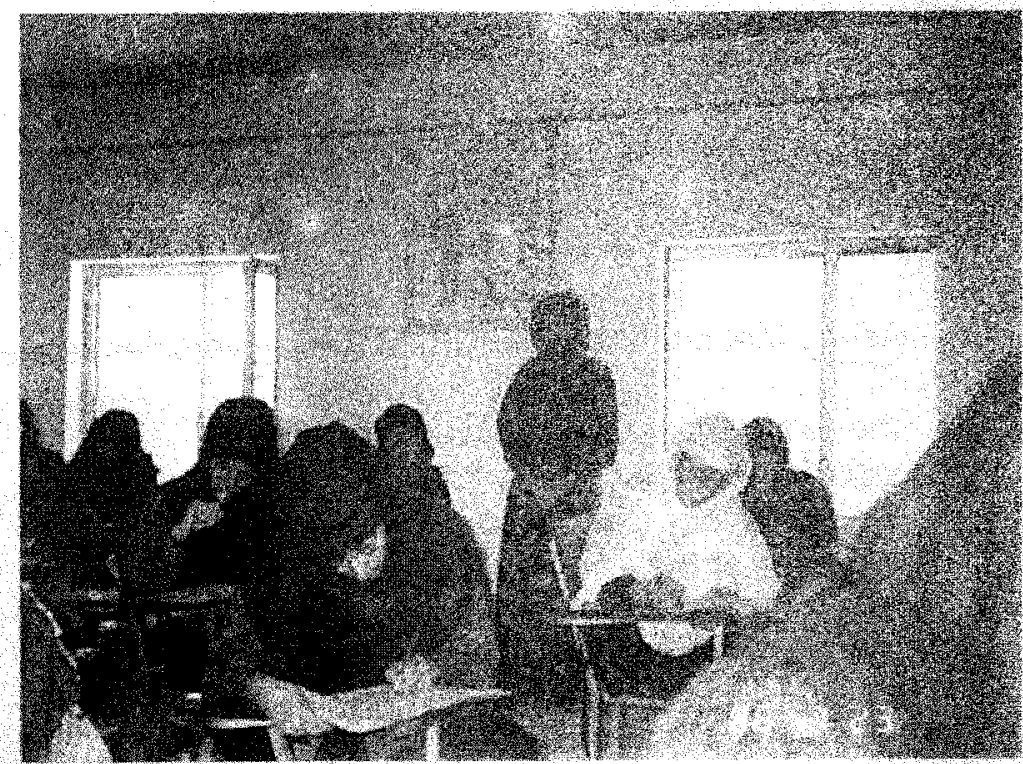

Examination in Progress

There have been also discussions by the Afghan authorities namely Ministry of Higher and Vocational Education, Kabul with the Momineen University during the pre Taliban period whereby they have been granted a proper site' in Kabul for the construction of the University. However, these have lapsed due to subsequent changes in the policies.

\subsection{Sub-standard quality of the universities}

This is yet another reason brought up as a case for the closure of the universities. As indicated above a final evaluation of these institutions was conducted at the behest of the local authorities in Peshawar. The arguments adduced for closure relate to the:

a) lack of basic facilities specially for the medical and engineering fields which includes laboratories. libraries etc;

b) lack of competencies in management;

c) quality of the curriculum

d) entry criteria;

e) comparability in examinations:

f) concept of university and applicability to these institutions and

g) more 'money machines' than academic

h) produce quacks

The university authorities have refuted these arguments by indicating that although they lack the facilities of a well developed university the basic facilities are met to a greater extent They argue that these are better than having nothing and compared to what is available inside Afghanistan the authorities feel that the attempts of these institutions are only the beginning. In due course of time they will grow. Some of the institutions we visited had libraries with consisted mostly of books in the field of medicine some of which have been written by the lecturers themselves (Hewad University). As for the labs modest attempts were seen in that Hewad University had a laboratory, operating theater, library hospital beds numbering 50 facilities for out door patients, a number of lecturer rooms with basic needs. University of Momineen had also a laboratory, teaching clinic and a library with 3500 books. 
Some of the universities use hospitals of some of the NGO's in Peshawar. such as Mercy International, Afghan Japan Hospital Albadar hospital, Mujahid Eye clinic. Mahamadi Heart Foundaton. Kuwaty hosoita! workshops where the students conduct ther house jobs during and after the courses. Engineering students also use the facilities of workshops of some of the NGO's while the fachities in the Peshawar university are made use of by agricultural students for thetr practicals. Further, Momineen University has a practising school with 250 pre-school children for training of teachers in Islamyat and literature courses. Although these facilities do not meet the ideal and lacks the quality of developed universities, one should understand that these / institutions are of the refugees for the refugees by the refugees. Futher, they are at the formative stages of developing higher education institutes and these attempts are results of the initiatives of the Afghan academics and elders in Peshawar.

It was also pointed out by the university authorities that the lecturers of these universities are mostly from the Kabul university and posses qualifications from universities in western countries India and Australia Thereby the quality of the academic personnel qualification wise is satisfactory, although we did not see the credentials personally. One university namely Momineen University, has been affiliated to the University in Malaysia Most of the lecturers seem to be very articulate and in their middle age, which means that they have the potential to serve for a long period with the universities

As for the curriculum all universities follow the curriculum of the Kabul university, which they say had been accepted by UNESCO at the early stages But there is no proof for this claim. Furthermore, the curriculum is developed for the Afghan pathology and comparisons may not be rational. Detail contents of the curriculum were provided to the UNHCR.

Basic qualifications for entry is a high school certificate, which is 12 years of schooling and an entry examination. Selections are done carefully so that only candidates who reach the criteria set by the university are admitted. Evaluations are also conducted regularly both theory and practice. The minimum score for a pass is 55 per cent and those who do not achieve this score have to repeat. For example 80 students in 1997 and 15 in 1995 from the Momineen university repeated the examination. It was also revealed that some drop out altogether. Those who perform well at the final examination are been absorbed as tutors to the respective faculties, as for example the Momineen University had employed 6 for the medicine 9 for Islanyat and 4 for literature as tutors over the last few years. Some of the universities follow the French models and not that of UK as in Pakistan in fact British influence is minimal in their educational programmes through out the history of Afghanistan.

The university authorities also pointed out that the medical degree of the Afghan universities cover a period of seven years, referred to as MD as against the Pakistani MBBS degree of five years duration.

The products of these universities are employed in hospitals in cities in Afghanistan such as Farah Herat Kabul, Ghazni and in the refugee camps, in addition to being employed in private clinics in Peshawar

The consensus of all the staff of the 4 universities regarding the quality seems to be the same They categorically indicated that as the Afghan universities are for the Afghans, the degree is for the Afghans, conducted by the Afghan professors, to serve the needs of the Afghans, the quality should be determined by the Afghans and not others.

As Afghanistan had been in a state of confusion and destruction both by outsiders and more by themselves the approaches to development should be of a different order. 'Even if we produce half a doctor we would be satisfied than not having any' was the curt reply of a vice chancellor. The dons feel that these been 
refugee universities it is natural that the institutions cannot possess all facilities of a high order as they are the 'products of a destroyed country'. They also pointed out that during the Russian invasion the Afghans established a university, Dawat-ul-Jehad, temporarily with medical and engineering faculties. It was established for emergency reasons and these dons feel the current universities are too based on the same emergency need. At the moment Pakistan provides only two seats in their medical colleges for Afghan students while the need is in hundreds.

A study conducted by NAC has a positive comments on the products specially of the products of the UMU. Accordingly the doctors of UMU ' were reasonably good doctors' who were following the house job at the Mercy International Hospital. They were well trained in providing the basic treatment and management as expected from a health personnel. Thus the views of this study conducted by a Pakistani doctor provides a positive impression on the products of the UMU.

It was also revealed that inter university meetings amongst the Afghans are held monthly on a faculty basis to discuss academic matters and other issues.

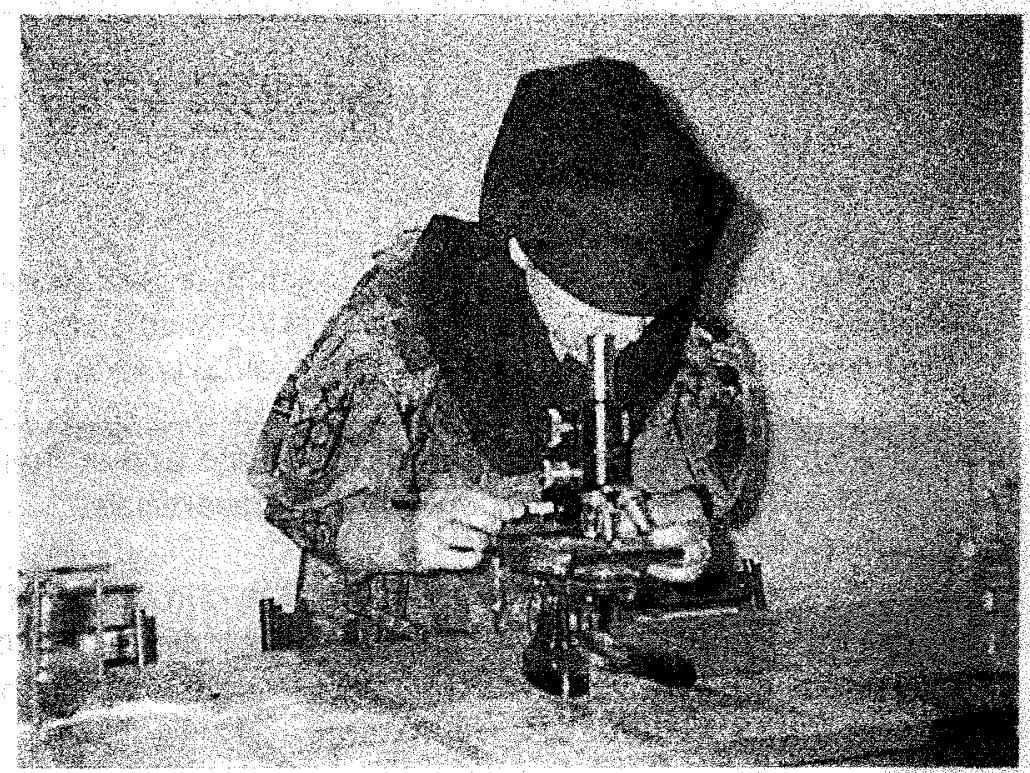

Student using Lab facilities

\subsection{Management}

The issue of management was also raised specially with the funding NGO, namely Nonwegian Afghanistan Committee (NAC) It was revealed that this aspect is very weak and needs upgrading and NAC had conducted a number of seminars for the benefit of the officers concerned at the Momineen University. NAC had hired a consultant from Peshawar since 1996 to assist in guiding the management aspects of this university. However, such a facility seems to be not available to other universities. Some universities had an organisational chart indicating the line of command and terms of reference to the respective positions. These indicate that the authorities were mindful of the responsibilities and had placed importance to management aspects

\subsection{Finance}

The allegations that these institutions are only money making was also looked into. The funding sources for the universities are solely from the fees collected except that of the Momineen university. This university which is for women receives assistance from NAC For 1997 the amount was PK. Rs 8.6 million. In addition it is supported by Muslim Sister Organisation which provided Rs. 18 million in 1998 All universities collect fees which range from Rs. 100 to 400 a month. The fees charged vary with sex females charged less than males and courses, medicine higher than others. Initially some of the unversities such as Ahmad Shah Abdali university had received small funds from the Canadian government and from the Asia Foundation. 
Table 2.

Sources of funds

\begin{tabular}{|l|c|c|c|c|c|c|c|}
\hline \multicolumn{1}{|c|}{ University } & NGO/Funds & \multicolumn{2}{|c|}{ Fees } & \multicolumn{3}{|c|}{ Charged } \\
\hline $\begin{array}{l}\text { Unmahatui } \\
\text { Momineen }\end{array}$ & NAC Rs. 8.6 m. & - & $100 /-$ & - & - & - & - \\
\hline $\begin{array}{l}\text { 2. Allama Sayed } \\
\text { Jamai Afghani }\end{array}$ & - & $300 /-$ & $200 /-$ & - & - & - & - \\
\hline $\begin{array}{l}\text { 3. Ahmed Shah } \\
\text { Abdali }\end{array}$ & - & - & - & $400 *$ & $350 /-$ & $230 /-$ & $200 /-$ \\
\hline 4. Hewad & - & $400 /-$ & $300 /-$ & - & - & - & - \\
\hline
\end{tabular}

* higher grades $500 /-$

Other sources of income in some universities derives from model clinics where a modest payment is made by the patients. Thus Momineen University charges a fee of Rs. 10/- per patient. Some essential drugs are provided to the patients. The clinics have all the necessary equipment both in Momineen and Hewad universities. However the income has to be spent on purchase of equipment and maintenance of the clinics. It is through contributions from the Afghan community and collection of fees from the students that these universities manage their activities. According to the university personnel it is not fair to compare the quality of the Afghan universities with those that have been established long ago with abundant resources.

The salaries of the university dons vary from Rs. 1500 to 7000 (Us \$ 25 to 110) with medical personnel drawing more than the others. The monies are spent on salaries, polyclinic expenses, stationery, transport, labs, site rent services, library, texts books, computer, maintenance etc. Transport is provided to all females students which seems to be of a high cost. Thus UMU spends 1 million rupees per annum to provide transport to the females and staff. Apparently this is one way to motivate the females to carry on their studies otherwise customarily girls are accompanied by an elder and very rarely venture alone in the city. Thus the monies coliected and received from donors are spent on activities that are essential. The salaries of the staff does not seem at all to be in par with similar personnel in other universities in the developing countries.

\subsection{Admissions of Pakistani students}

Another point of concern of the authorities, though not mentioned directly, is the admission of Pakistani students to these universities. The local authorities fear that the low quality of the products will affect later the services they would provide in Pakistan. However inquiries into this aspect indicated that these students from Pakistan are those who have been following courses in Kabul and Mazar-I-Sharif earlier and due to closure of universities and other problems they have opted to join the Afghan universities in Peshawar. Even in Kandahar there are nearly 200 Pakistani students studying. 


\subsection{Reactions from Taliban leadership}

By and large the Talibans are pre occupied with the war and other political matters. Female education does not concern them very much. However they need personnel to run the state machinery specially the medical personnel at the moment.. These universities had contacted the Taliban leadership and had been advised to include Sharia in the curriculum. The matters related to the closure of the universities have also been taken up with them. In fact, the Taliban Minister of Higher and Vocational Education was expected to visit Peshawar in early October, 1998. At the time of writing this report there has been no communication about what transpired between the Minister and the NGO organisation, ACBAR, which is supposed to take up the cause with the minister. In addition the universities have approached the Afghan consulate in Peshawar requesting them to bring the issue to the notice of the Taliban leadership in Kandahar, namely Mullah Omar so that he could discuss the problem with the highest authorities in Pakistan. Further, the Talibans have agreed to provide facilities to the Universities if they come back to Afghanistan but no promise has been made regarding the education of the females.

Inspite of the positive attitudes of the Talibans they seem to be concerned about the political backlash that may emerge from the products of these universities. They fear that these institutions could be hot beds of communists or at least favour more progressive ideas contrary to the policies of the Talibans. These are feelings and fears unexpressed forming part of their hidden agendas.

$i ;$ 


\section{4}

\section{PROBLEMS ENCOUNTERED BY THE STUDENTS}

These relate to the following

1. lack of hostels

2. difficulties related to studying at home due to lack of space with too many guests/visitors

3. transport problems for the male students since some of live in far away camps

4. economic problems related to maintaining of a family in case of some students

5. difficulties during both summer and winter in the lecturer rooms due to lack of cooling and heating facilities

6. lack of books and library facilities

7. lack of facilities for practicals due to more students than could be accommodated

8. large numbers in the groups

9. difficulty to read questions during examination times due these been written on the black board

10. lack of photo copiers

However the students feel that there is no corruption in the examinations and testing procedures. A greater majority of the students wish to get back to Afghanistan when ever it is convenient. There are some who may not be willing to return due to their commitments in Peshawar such as marriage, involvement in commercial activities such as small business, drivers, bread winners to the family etc.

\section{Females}

1. Economic problem. This relates to the investment they have made so far on their education at the university. Over $85 \%$ of the parents of the students have no jobs and even those employed are either working in jobs which are of a lower category or the income from these are very marginal for a family. The students have thus exhausted even these little sources of income and are now are left in the lurch. They were hoping to complete their studies and seek some employment to assist the family. They feel that they have wasted their meager resources.

2 Inability to do anything further. Some are already engaged and if they get married soon their education will terminate, as the Afghan society does not permit to commence studies after marriage. Thus the students feel all what they have cared for and aspired to will end up in smoke.

3. Initially when they decided to enter the universities the responses of the parents and elders were not favourable. Now that they have to leave or abandon their studies brings additional frustrations which are increased by the negative views of the elders.

Nevertheless most of them feel that what they have learnt will be helpful in their future life as members of the community. 


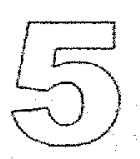

\section{IMPACT OF CLOSURE ON THE STUDENT}

These were demand-oriented universities. They emerged as a result of the need for tertiary education caused by large numbers of refugee children moving up the cycles from primary to secondary and beyond over the last 15 years as refugees. It would be interesting to note that the student population in the refugee camps increased appreciably over the last few years. Thus for example the number of students has risen from about 58,000 in 1996 to 83,000 in the schools in the refugee camps in the NWFP. which amounts to an increase of almost 40 per cent in 2 years. The increase in the number of girls have been also satisfactory during the same period of time. All these means that the desire for learning amongst the refugees has been increasing resulting in their advancing to higher grades and the brighter ending up at the doors of the unversities. Hence why the rationale for the establishment of universities.

The universities have been able to keep the youth in very productive and human resource development activities rather than involving in a culture of war. This is the concern of both students and teachers as well as parents. Further they feel that in a time of peace the products of these universities would be an invaluable to assist the government machinery. They strongly feel that these youth could form the resource base of the future of the country. Thus the shortcomings that exist currently should not be taken as a reason for any disturbance to the learning process of the Afghan youth. Lack of opportunities would lead them to get involved again in anti social activities which are in abundance in the environment. Drug trafficking, smuggling, theft, gang rivalry are but a few of the areas that would appeal to these youths. More important is the loss of opportunity for the girls. They will be the most frustrated youth without having to do anything in their life. The stress would also affect those in the high school who will find that there is no future in pursuing studies. That will cause another disaster for one of the reasons for Afghans to migrate is the opportunities for education in Pakistan. But when they find that the doors for higher education are shut before them, it would have a highly negative effect causing serious simmerings in the social fabric.

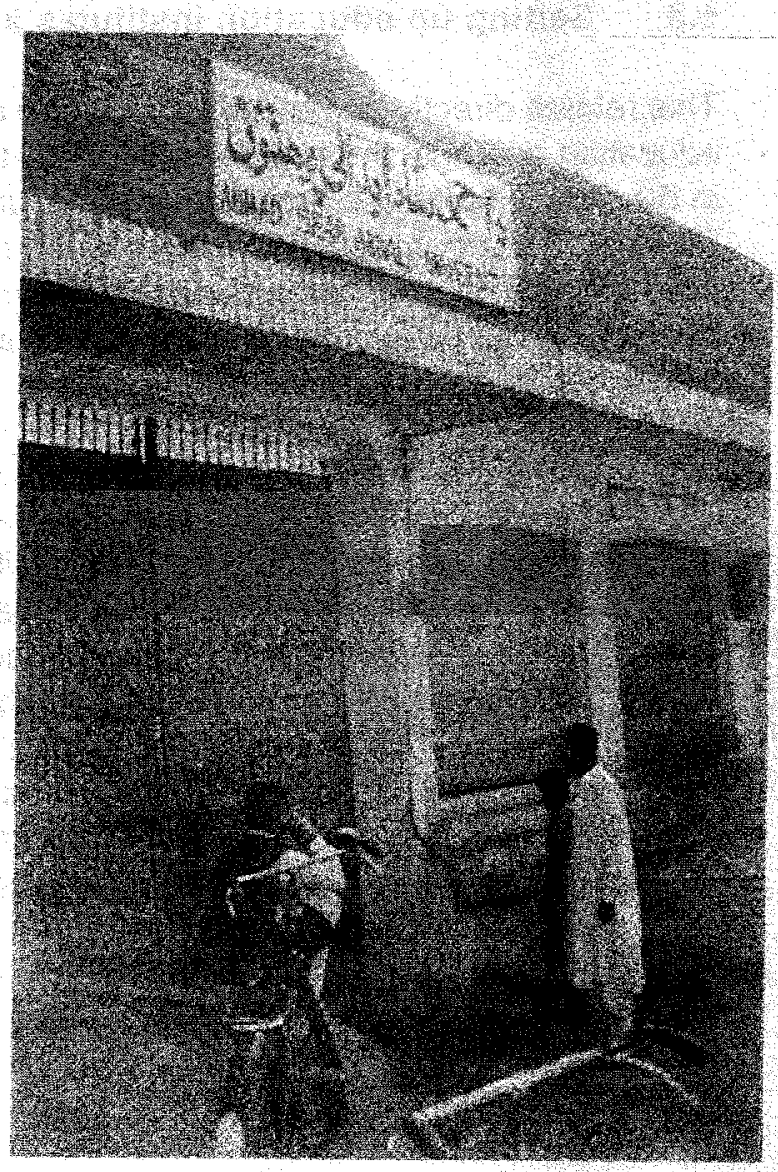

Males Locked Out

Although the researchers could not meet the local authorities they were able to discuss the issue with a few Pakistanis in Peshawar. Their opinion based on their observations of what has been happening over the years is recorded here, although it may not be the official version. 


\subsection{Hospitality fatigue}

Afghans who have been welcomed with the traditional hospitality as brothers two decades ago are not showing signs of leaving the soils of Pakistan. During their stay the Afghan have almost taken over certain areas in the city of Peshawar around Hayertabad. The social life of the citizens has been disturbed and intruded. There are cultural and social implications of their continuous stay. The fact that there have been clashes over the years between these groups indicate the pressure that is building up

\subsection{Commercial competitions}

This seems to be another key cause for the conflicts. One would see that small business . transport services timber trade etc. are almost entirely in the hands of the Afghan refugees. They seem to be very articulate to use every opportunity to generate income for survival. Although this is appreciated. it has caused loss of opportunities for the local in many ways.

\subsection{Setting up education institutes and employment}

This relates directly to the issue of closure of the universities. While appreciating the great interest created in education amongst the refugees, they feel that these may cause problems related to employment in Pakistan in the future, since the products of these universities may likely to compete for jobs with the graduates from Pakistan. Further, as these institutes are newly established possessing meager resources the quality of the products will be of a lower standard which will affect the services provided by them in Pakistan. Since the medium of instruction of these universities is mostly in Pastu/Dari the possibility of seeking employment in the developed countries is also remote.

\subsection{Delaying the desire to go home}

The establishment of higher education institutes will delay the repatriation as opportunities for learning inside Afghanistan are not available. In the case of the females the situation is much graver with the policy of Talibans depriving females access to education. Seemingly the concerned feelings of the host country is understandable where they have their problems of higher education and employment. It is the responsibility of the international community to take pro-active measurers with long term visions to ease the fears of the host country. The UN along with the international agencies should emphasis the need for quality education inside Afghanistan and heavy emphasis be paid on this sector. As it is over the years only lip service has been given to education, although 'capacity building' and 'empowerment' are two key words flung around at meetings and in most reports/proposals for funding.

$$
\text { is }
$$




\section{FINDINGS}

\section{FINDINGS AND RECOMMENDATIONS}

1. The understanding among the university personnel about the authority from whom the final decision regarding the establishment of the institutions should be obtained seemingly differs from that of the local authorities. Most universities have obtained a ' no objection certificate' (NOC) from the commissioner for Afghan refugees, NWFP. They feel this to be the final authority since the commissionarate overseer all political, social and other issues concerning to the refugees.

2. The underlying fears of a grieved party, ie the Afghans, and the hosts, i.e the Government of Pakistan, seem to be both justified. The Afghans need for education has to be supported and fostered in accordance with the UN charter. However, the modus operandi has to be suitably worked out in collaboration with the host country. The fears of the latter relate to the period of two decades of hospitality still without any solution with attendant ramifications on the social, cultural, economic and political aspects.

3. The conditions under which these institutions function have to be viewed from contexts rather than from ideal situations. Although the facilities are not entirely satisfactory the efforts of the Afghans should be appreciated. They are still in their formative stages and institution building is a long process unless backed by significant funding.

4. There was a lack of foresight and proactive approaches by the international community regarding the trends of the education process and the inability to discern that at the end of 15 years of schooling Afghan refugee children are likely to demand facilities for higher education have led to the current issues.

5. The increase in the females proceeding to tertiary education. Of the nearly 3000 students over 1250 are females ( $40 \%$ ), which is very encouraging and compares well with most of the developing countries. This momentum has to be maintained and supported

6. Use of Afghan capacities and resources in the running of the institutions. Instead of obtaining experts/consultants from elsewhere they have relied on their initiatives. Significance of this approach lies specially in the light of the current resource limitations.

7. These universities could form the basis for the promotion of men's and women's education and the establishment of five universities inside Afghanistan as is called for in the memorandum of understanding (MOU) signed between the Islamic Emarate of Afghanistan and the UN.

8. The stress of the students specially the females and the possibility of males involving in anti-social activities and possibly driven away from a culture of peace back to culture of war due to despondency.

9. Impact on repatriation. It may be possible that opening of the universities in Peshawar may dampen the Afghans returning back to their own country and specially those of the educated groups. This may be one of the concerns of Pakistan and also of the Talibans for a different reason. in that they may not be able to develop their institutions and human resources immediately. 


\section{RECOMMENDATIONS}

\section{Short term}

1. The universities at the moment function as mixed except one. Further these universities are located too close to each other in the same locality, within short distances to each other. Combining of the three male universities into one and separate university for females .in order to pool resources, both human and material and in keeping with the cultural norms could be one alternative. The other would be to establish one university for both sexes but learning to take place seperately, though this option has little chance of materialising. Both these options will save wastage of resources and improve the quality of the output.

2. Till such time the above comes into operation the universities to be opened on a temporary basis to enable those in the final year to complete their degrees. However, immediate action to be taken on the reopening of the universities without jeopardising the education of the Afghan students who are already in the universities.

Adoption of a common criteria for admissions, a common curriculum and an evaluation for all universities in order to standadise the quality.

$4 \quad$ Sharing of resources including personnel between the universities

5. An agreement to be arrived at between the government of Pakistan and the University personnel including the Commissionarate.

6. A clear set of rules and regulations to be developed for students

7. Regulations for admission of foreign students/ concurrence by the government of Pakistan

8. UNHCR, both Islamabad and Kabul, may have to intervene in these matters and develop a clear policy framework on education for refugees, which will help to guide these independent initiatives.

9. UNHCR to assist the universities to obtain registration of their universities in Pakistan.

10. The Afghan government should provide support by way of providing employment to those who pass out from these universities, as well as commence seriously in organising their universities to accommodate those who are eligible for higher education. This will be one way of encouraging refugees to return to Afghanistan.

11. Till such time the universities inside Afghanistan are well established, the Afghan authorities should assist the university education in Pakistan, specially for females as the Talibans always state that there is no security for girls inside Afghanistan.

\section{Long term}

12. Providing facilities for quality education for both sexes in side Afghanistan to encourage repatriation

13. Training of key educational personnel in various fields to take the mantle of leadership

14. Guidance to the faculty of education in these universities in relation to Afghan issues

15. Study on the educational facilities available/needs from primary to tertiary amongst the refugees

16. Heavy emphasis to be laid on education by the international community as part of repatriation and rebuilding of Afghanistan

$$
\text { is }
$$




\section{Fact Sheet of Universities}

\section{Hewad University}

\author{
Year of establishment \\ Faculties \\ Curriculum
}

Registration in Pakistan

Terms and conditions of admission in the institute

Facilities

Funds

Fees

Male

Female

Total number of students 1st April 1997

Medical and Para Medical faculty

Same as Kabul University which is recognized by UNESCO

Registered with the commissioner Afghan refugees NOC with No. CAR/DC(R)97/5537

F.Sc. or equivalent examination i.e. high school graduates/preliminary test before admission

hospital of 50 beds, library, Laboratory for practical work , blood test, E.C.G etc. 200 rooms building for college and hospital

Pir Ahmad Gilani

$400 \mathrm{Rs}$

$300 \mathrm{Rs}$

Male $=448$

Female $=102$

Number of students graduated: None

Hostel facility male's hostel and charge 350Rs

Total Number of teacher

40

Teacher's salary

Teacher's qualification

Total no of Pakistani students

Transportation
Afghanistan, Russia, Pakistan, London, Ucrain, Germany, Egypt, U.S.A. France.

None

Provided 


\section{University of Allama Sayed Jamal-ud-Din Afghani}

Year of establishment:

1995

Faculties

Registration in Pakistan

Terms and conditions of

Facilities

Curriculum

Funds

Fees

Total no of students

Total Number of Pakistani student

Number of students graduated

Hostel facility

Total Number of teachers

Teacher's Salary

Professor's qualification

Transportation
Medical, Engıneering. Agriculture. Literature, Journalism. Theology

Applied for NOC but still there is no response

F.Sc. or equivalent examination i.e high admission school /Preliminary test before admission

Laboratory, Clinic, Library.Agencies with the practical and field work of the students. ACLU, DACAAR, BBC.Peshawar Agriculture university, Nursery farms

Same as Kabul university which is recognized by UNESCO and UNICEF

Self established and had not received any financial support The university is running by the monthly students fees. Norwegian had promised to provide assistance for 1998 and with the proposed extension for three years

300 Rs. Male

200 Rs. female

650 students 250 female students 450 male

30 students

None

\section{8}

$2.400-2.900 \mathrm{Rs}$

Kabul University, Nangarhar University, and Ph.D. obtained from different Universities like France, India, USSR.

For female students only 


\section{3. $\quad$ Ahmed Shah Abdali University}

Year of establishment

Faculties

Registration in Pakistan

Terms and conditions of admission in the institution

Facilities

Funding agencies

Fees per month

Total number of students

Number of students graduated:

Number of Pakistani students:

Hostel facility

Total number of the teachers :

Male

Female

Teachers Salaries

Qualification of teachers
1993

Engineering,Agriculture Medical. political Science,

Shariat and Islamic Law

Registered with Afghan Commissionerate

NOC from Afghan Commissionerate no: $268 /(4-s) / s / A R$,

Government of Pakistan, Ministry of Education, Islamabad

Pakistan Medical and Dental Council

(No.PF-97-F95-SCH-111)

F.Sc. or equivalent examination i.e. high school graduates/ preliminary test before admission

Female section laboratory funded and equipped by Canada Government;

Female Audio visual laboratory; Male section laboratory Male Audio visual Laboratory; Same as Kabul university which is recognized by UNESCO

It was established independent of any external financial assistance from NGOs or political organization. It operates solely on the basis of monthly students fees. It had received some funds from Canadian funds for equipping their laboratory.

Norwegian Committee

Medical $=400 \mathrm{Rs} \quad$ Higher classes $=500 \mathrm{Rs}$

Eng $=350 \mathrm{Rs}$ Agriculture $=230 \mathrm{Rs}$

Shariat and Law 200Rs

1247

Male 1035; Female 212

Number of students graduated

15 Students in Medical and 10 students in Engineering (25 students)

Provided

88 teachers

79 teachers

11 teachers

3,000-4,500Rs

30 have got $\mathrm{Ph} . \mathrm{D}$. or equivalent certificates. 


\section{Ummahat-ul-Momineen University for Women}

Year of establishment

Faculties

Authorization

Facilities

Curriculum

Funds

Fees of the students

Total number of students

Number of Pakistani students

Hostel facility

Total number of teacher

Students graduated

Teachers salary

Teachers qualification

Transportation
1990

Medical, Science, Literature, Shariat

(Islamic Law) and Education

Registered with Afghan Commissionerate

Mercy international, Afghan Japan Hospital.

Mujahid Eye Clinic, Mohammadi heart

Foundation and Kuwait Red cross

Same as Kabul university

Entirely from external sources, namely

NORAD/FOKUS. Some income is generated through the students income.

Asia Foundation uptill 1994

Muslims sisters organization of Afghanistan (MSOA)

Afghan NGO.

100 Rs per Month

730 girls

Non

-..

95

200 students

For Medicine 3000 Rs - 7500 Rs

Art Section 1500 Rs - 6500 Rs

Afganistan, Russia, Pakistan, India, France. Germany, U.S.A., England, India, USSR, Australia, Japan and other countries

Provided 
Annex - II

\section{COURT DECISION}

\section{Press cuttings}

Peshawar High court dismisses petitions against closure of medical varsities. A division of Peshawar High court (PHC), challenging the closure of two private Medical universities (Ahmad Shah Abdali and Cenna Medical college). The court comprising the Chief Justice, Mehbob Ali Khan and Justice Main Mohammed Ajmal.

-The Frontier Post Wednesday 30th September 1998.

A Division Bench Peshawar, High Court (PHC) on Tuesday dismissed two identical petitions, challenging the closure of private professional educational institutions in Peshawıar. The News Wednesday 30th September 1998.

is $i$ 


\section{Schedule 1 \\ University Personnel}

\section{Data collection/discussion}

\section{Basic data}

1. year of commencement of the institution

2. number of students by year and sex

3. basic qualifications for admission and methods of recruitment

4. fees levied on the students item-wise annually

\section{Facilities}

1. facilities available for academic and non academic activities

2. problems related to provision of facilities.

3. financial support received yearly since inception/donors/budgetary issues

4. nature of the support from Pakistan or others - land/buildings/logistics/technical etc

\section{Performance and acceptability}

1. peiformances of students/pass failure rates sex-wise

2. types/methods/stages of evaluation conducted

3. application of students on studies/drop out rates/reasons/quality

4. qualifications of staff/experience/no/ sexwise

5. impressions of the students about the course

6. views about the curriculum/traditional/needs oriented/theoritical

7. comparability with Pakistani levels

8. acceptability of the degree for post graduate studies

9. recognition of the degrees by the international community

\section{Employment}

1. employment opportunities /how many employed locally and elswhere/sexwise

2. issue related to employment

3. acceptability by Talibans inside Afghanistan

4. reactions of the local community to the establishment both positive and negative

5. application of students on studies/drop out rates and reasons

6. no. of Pakistani students and the nature of interactions

7. qualifications and experiences of staff/no. on the staff sexwise 


\section{Issues}

1. reasons for closure/ when/who were responsible/documents

2. opinions about the closure/impact/political/pressure groups/economic etc

3. links to repatriation/encouragement/indirect methods

4. if universities developed inside will they return/staff/students/parents

5. nature/type of relationships with local students/professionals/universities, what types/how often

\section{Schedule II Commissionarate}

1. number of students at educational institutions - schools/technical institutes/universities

2. number of employed Afghans in Peshawar/sex wise

\section{Facilities}

1. facilities provided by the state for the university/higher education in terms of cost and infra structure NWFP/elsewhere

2. impact of the education of Afghans on $P K$ students in terms of loss of opportunities/facilities etc.

3. basis of provision of education for Afghan children at the initial stages /secondary/university

4. issues related to the provision of education to Afghan students/parents/religious leaders/politicians/educationists/administrators/community

5. basis on which facilities were provided to the Afghans at the initial stages

\section{Reasons for closure}

1. reasons for the closure of the universities/political/economic/cultural/ management/quality/facilities etc.

2. impact of the closure on Afghans/repatriation

3. future policies of the state to Afghan social development problems

4. basis on which facilities provided to the Afghans at the initial stages

5. nature of the stress of the refugees on the state of Pakistan / financial/management/ facilities/population/health/education/land/commerce/employment/social and cultural aspects etc.

6. suggestions for future steps related to refugee problems

\section{issues}

1. law and order as a relationship to closure

2. indirect attempt to encourage repatriation

3. opportunities for employment of Afghan graduates 


\section{Schedule III \\ Students}

\section{Background information}

1. background information about the students / qualifications/age/sex/place of origin/period of stay/primary education/secondary education/course of study

2. reasons for stay in Pakistan/refugee

4. aspirations for the future and the desire to return

\section{Problems/advantages of a refugee}

1. problems as a refugee/social/ economic/cultural/

2. advantages of being a refugee / education/social/economic/opportunities etc.

\section{Assessment of the institutions/courses}

1. views about the institution /quality of education/facilities available/cultural affinity/lack of harassment/ social; acceptance etc.

2. reasons for not joining a Pakistani university /problems related to admission/costs/ social/cultural/higher standards

3. importance of the courses/relevance/linkages to employment

\section{Financial issues}

1. expenses involved/living/materials/fees etc.

2. sources of funding / parents/part time work/friends/relations/grants/donations

3. problems encountered/ education/living and nature of problems/ sources of problems

\section{Reasons for closure/plans}

1. reasons for the closure

2. alternatives to continue studies

3. action taken to request reopening and results/with whom/opinions

4. impact of the closure on the future students/where to go/financial etc.

5. desire to get back to Afghanistan

6. views about how education could help stability/democracy/development etc. 


\section{Schedule IV \\ Parents/community members}

\section{Background information}

1. background information / no.of children/ages/sex/when migrated/where they live/employment/sources of income/problems of living

2. desire/plans to return/priorities for returning

\section{Reasons for migration}

1. reasons for migration/security/loss of property/education/ etc.

2. education of children/where/expenses/levels/desire/reasons

3. facilities provided for the education of the child

\section{Views about the closure}

1. opinions about the closure

2. action taken on the closure to date/whom met/results etc.

3. plans for the future education

4. opinions about the assistance from local authorities for education

\section{Schedule V \\ N.G.O's}

1. support provided for university/higher education of the Afghans ? what form/how long/amounts/loans/numbers involved $\mathrm{m} / \mathrm{f}$

2. relationship with the universities/member of board/consultation/academic/non-academic

3. views about the quality/progress/certification of the institution

4. why they think university/higher ed. institutions useful

5. views about the closure

6. suggestions for the future

\section{Senior Officials/Politicians}

Some key questions for discussions to be developed based on the above schedules 


\section{3-29 September 1998}

\section{Schedule VI \\ Time schedule}

finalising the instruments/ informing the UNHCR Peshawar/informing the universities/NGO's/ senior personnel commissionarate/Ministry of education/politicians (all through UNHCR office) Peshawar sub office)

30 September pm Departure to Peshawar

1 October (Thursday)

$08.00-10.00$ meeting UNHCR colleagues

10.30- 13.00 meeting university personnel

$13.30-17.30$ contd.

2 October (Friday)

$09.00-12.00$ meeting officers from the commissionarate

14.00 - 18.30 meeting students - (6)

\section{October (Saturday)}

09.00 - 12.00 meeting students (8)

14.00 - 16.30 meeting community members/parents (4)

\section{October (Sunday)}

whole day - meeting students/:parents /community members (12)

\section{October (Monday)}

$08.00-12.00$ - meeting Ministry of Education Officials

$13.00-17.00$ - meeting political personnel/both government and opposition

\section{October (Tuesday)}

08.00 - 16.00 - meeting NGO personnel

18.00 - departure to Islamabad

\section{7-10 October}

analysis of data

15 October $1^{\text {st }}$ draft report

15-17 October discussion

25 October final report ready for printing 


\section{PERSONS INTERVIEWED}

UNHCR Peshawar

Norwegian Church Aid

Norwegian Afghanistan

Committee

ACBAR

BEFARE

Soliderate Afghanistan Belgium

\section{University Personnel}

Hewad University

Ummuhatul Momineen

Amed Shah Abdali

Sayed Jamal Ud Din Afghani

Students

Parents
Marie-France Sevestre, Head of Sub Office

Niaz Mohammed. Associate Programme Officer

Lina Yusiufi, Programme officer

Mohd. Ihsaan H.R.D.S

Oddvin Forbord, Director

Eng. Azizurrahman Raffiee, Programme Officer

Dr. Ahmed Nuristani, Director

Amir M. Ahmadi. Programme Director
Dr.Bakhter Aminzay, Vice Chancellor

Dr.Nadir Hassas, Assistance Prof

Maryum Jan, Female Administrative Officer

Mohd. Nabi Ali, Vice President of Ummahat-ulMomineen University

Faiza Meharabi, Dean of Academic Affairs

Dr.Malali, Associate Professor

Zarghoona, Dean of Students Affairs

Asifa Kaker. Associate Professor

Dr. Totta Khail, Acting Vice Chancellor

Azizzulah Nissri, Head of Literature Depart.

Boys and girls

Parents and Guardians of the students 